\title{
Presentation of squamous cell carcinoma in pre- existing cutaneous sarcoidosis
}

\author{
Puo Nen Lim, Lisa Kirby, Grant Wylie
}

Dermatology Department, Stobhill Hospital (New), Glasgow, UK

\section{Correspondence to} Dr Puo Nen Lim; puonenlim@hotmail.com

Accepted 28 June 2020

\section{Check for updates}

(C) BMJ Publishing Group Limited 2020. No commercial re-use. See rights and permissions. Published by BMJ.

To cite: Lim PN, Kirby L,
Wylie G. BMJ Case Rep
2020;13:e236426.
doi:10.1136/bcr-2020-
236426

\section{DESCRIPTION}

A 66-year-old man was referred to dermatology department in view of a rapidly enlarging nodule at the right postauricular area presenting over several weeks. The nodule developed within a $2 \times 2 \mathrm{~cm}$ plaque of pre-existing cutaneous sarcoidosis (figures 1 and 2). He had been diagnosed with multisystem sarcoidosis in 2015, affecting both lungs and skin. Skin biopsy of the plaque at that time showed non-caseating granulomatous inflammation, in keeping with sarcoidosis. This was treated with topical clobetasol propionate, which reduced the plaque size. He had no significant past medical history and was not on any immunosuppressants. He had a history of moderate sun exposure and was Fitzpatrick skin type II.

Diagnostic biopsy of the new nodule showed appearances consistent with primary cutaneous squamous cell carcinoma (SCC). He subsequently underwent formal excision of the whole skin lesion. Histology revealed a poorly differentiated SCC with perineural invasion and infiltration to the subcutaneous tissue. A lymph node in the deep tissue was involved with an extracapsular spread. Further wider excision with neck dissection was subsequently performed, with additional involvement of a lymph node with no extracapsular spread. This was staged at UICC TNM8 pT3 PN3b. Staging CT neck, chest and abdomen did not reveal any overt metastases but confirmed persistent mediastinal and abdominal lymphadenopathy unchanged from previous imaging. This was discussed at regional multidisciplinary team and he subsequently underwent adjuvant radiotherapy to the site.

Sarcoidosis is a systemic disease of unknown aetiology characterised by non-caseating granulomas in multiple organs, most commonly the

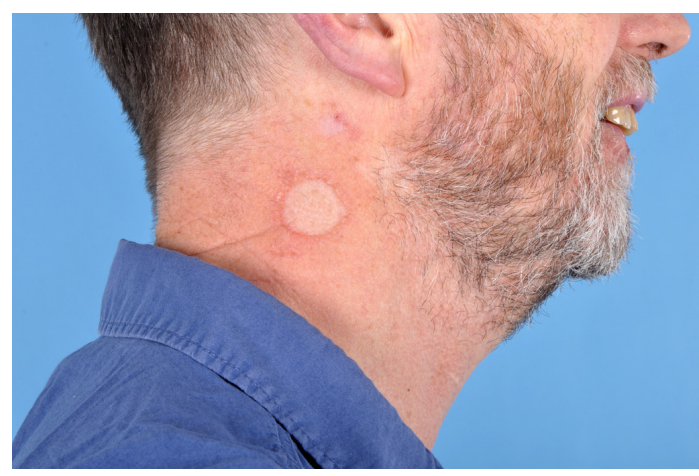

Figure 1 Pre-existing cutaneous sarcoidosis with an annular area of hypopigmentation at right postauricular area.

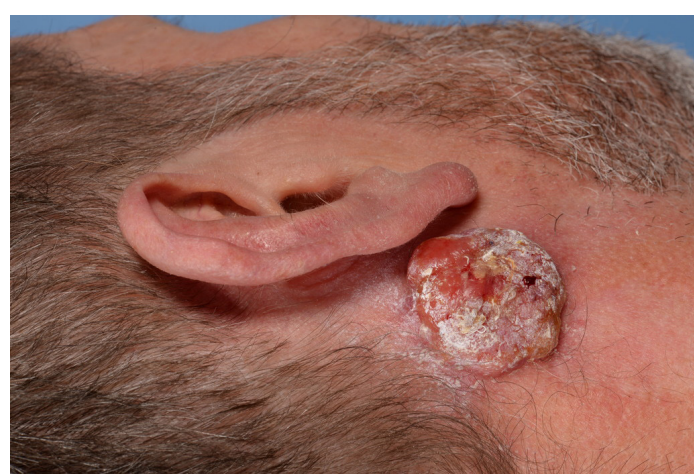

Figure 2 Squamous cell carcinoma at right postauricular area with hypopigmented resolved area of cutaneous sarcoidosis inferiorly.

lungs. Cutaneous involvement occurs in up to $25 \%$ of patients, with isolated cutaneous sarcoidosis present in 9\%-30\%. ${ }^{1}$ Cutaneous manifestations are highly variable, which can make initial diagnosis challenging.

Association between sarcoidosis and malignancy has previously been proposed. Several studies have reported higher rates of malignancy in sarcoidosis, most commonly lung and haematological malignancies, such as lymphoma. ${ }^{2-5} \mathrm{~A}$ systematic review involving over 25000 patients concluded a significant association between sarcoidosis and skin malignancy. ${ }^{6}$ The relative risk was 1.64 (95\% CI, 1.16 to 2.31) for melanoma and 2.29 (95\% CI, 1.88 to 2.78) for non-melanoma skin cancer compared with the general population. This was reiterated by Ji et al in Sweden who concluded that the increased risk of skin malignancy, specifically SCC, persisted even after a year following sarcoidosis diagnosis. ${ }^{5}$

Reports of SCC occurring within areas of cutaneous sarcoidosis are limited to case series. ${ }^{7}$ It is postulated that sarcoidosis and malignancy may be related to immune dysfunction leading to abnormal cell-mediated responses to tumour antigens. ${ }^{8}$

\section{Learning points}

- There is a strong association between sarcoidosis and skin malignancy.

- Immunosuppression in the treatment of sarcoidosis may lead to the development of skin malignancy.

- Clinicians should have a low threshold for investigating for skin malignancy in the event of changing lesions in areas of cutaneous sarcoidosis. 
Immunosuppression in the treatment of sarcoidosis may play a role in the development of malignancy. One case reported that the patient was treated with (anti-Tumour Necrosis Factor) adalimumab prior to developing an SCC. ${ }^{7}$ Notably, our patient had applied super potent steroid to the affected site.

In conclusion, we present a case of squamous cell carcinoma developing within a plaque of chronic cutaneous sarcoidosis. Hence, it is vital for clinicians to have a suspicion for skin malignancy and perform early skin biopsy in new or changing lesions in areas of cutaneous sarcoidosis.

Contributors PNL collated the data and wrote the first draft. LK reviewed the manuscript and wrote the second draft. GW provided consultant care and reviewed the manuscript.

Funding The authors have not declared a specific grant for this research from any funding agency in the public, commercial or not-for-profit sectors.

Competing interests None declared.
Patient consent for publication Obtained.

Provenance and peer review Not commissioned; externally peer reviewed.

\section{REFERENCES}

1 Alexandrescu DT, Kauffman CL, Ichim TE, et al. Cutaneous sarcoidosis and malignancy: an association between sarcoidosis with skin manifestations and systemic neoplasia. Dermatol Online J 2011;17:2.

2 Brincker H. Sarcoid reactions and sarcoidosis in Hodgkin's disease and other malignant lymphomata. Br J Cancer 1972;26:120-8.

3 Brincker $\mathrm{H}$, Wilbek $\mathrm{E}$. The incidence of malignant tumours in patients with respiratory sarcoidosis. Br J Cancer 1974;29:247-51.

4 Cohen PR, Kurzrock R. Sarcoidosis and malignancy. Clin Dermatol 2007;25:326-33.

5 Ji J, Shu X, Li X, et al. Cancer risk in hospitalized sarcoidosis patients: a follow-up study in Sweden. Ann Oncol 2009:20:1121-6.

6 Bonifazi M, Bravi F, Gasparini S, et al. Sarcoidosis and cancer risk: systematic review and meta-analysis of observational studies. Chest 2015;147:778-91.

7 Berg SA, Novoa RA, Stewart C, et al. Sarcoidosis and squamous cell carcinoma: a connection documented in a case series of 3 patients. Cutis 2016:98:377-80.

8 Reich JM, Mullooly JP, Johnson RE. Linkage analysis of malignancy-associated sarcoidosis. Chest 1995;107:605-13.

Copyright 2020 BMJ Publishing Group. All rights reserved. For permission to reuse any of this content visit

https://www.bmj.com/company/products-services/rights-and-licensing/permissions/

BMJ Case Report Fellows may re-use this article for personal use and teaching without any further permission.

Become a Fellow of BMJ Case Reports today and you can:

- Submit as many cases as you like

- Enjoy fast sympathetic peer review and rapid publication of accepted articles

- Access all the published articles

- Re-use any of the published material for personal use and teaching without further permission

Customer Service

If you have any further queries about your subscription, please contact our customer services team on +44 (0) 2071111105 or via email at support@bmj.com.

Visit casereports.bmi.com for more articles like this and to become a Fellow 